\title{
Rainfall Returns Periods in Iraq
}

\section{Hussein Ilaibi Zamil Al-Sudani*}

Petroleum Technology Department. University of Technology. Baghdad. Iraq.

dr.hussein_alsudani@yahoo.com, 150098@uotechnology.edu.iq

\begin{abstract}
\begin{tabular}{|l|l|l} 
Submission date:- 11/12/2018 & Acceptance date:- 8/1/2019 & Publication date:- 2/5/2019
\end{tabular}
Abstract

Rainfall date obtained for thirty-two meteorological stations distributed in Iraq to find the rainfall returns period, which contributes in the improvement of water management plans all over Iraq, especially during dry seasons. Mean annual summation of rainfall has a symmetrical increasing pattern from southern west towards northern east, according to the increasing ratio of rainfall in the northern region of Iraq. The northern east region of Iraq has characterized by very abnormal and abnormal events regarding rainfall (P) in term of return periods, while the northern west, middle and southern regions characterize by a normal distribution of rainfall. , Iraq has only two types of weather conditions, according to rainfall returns periods: the humid weather condition located in the northern east part and dry weather condition in the other parts of it.
\end{abstract}

Keywords: Annual and Monthly Rainfall, Meteorological Data, Returns Period, Iraq.

\section{Introduction}

Rainfall is one among the main components of hydrological cycle and is considered as principle source of water to the earth [1]. The changing in the seasonal rainfall has greatly effected on runoff, evapotranspiration and infiltration, although, the changing in annual total rainfall could be absent which effects on responsibility of ecosystem, stream discharge and flood forecasting [2]. Rainfall varies geographically, temporally and seasonally where the total rainfall received in a given period at a location is highly variable from one year to another [3]. The variability depends on the type of climate and the length of the considered period. The average of rainfall gives information on the normal amount of rainfall one can expect in the area. It can be used to obtain an idea of the departure of the annual rainfall from the normal, or to compare climatic regions. Because of the strong variability of rainfall in time, the design and management of irrigation water supply and flood control systems are not based on the long-term average of rainfall records, but on particular rainfall depths that can be expected for a specific probability or return period [4]. Return period $\left(\mathrm{T}_{\mathrm{x}}\right)$ is one of the important objectives of frequency analysis to calculate the recurrence interval or return period. The return period (also called the recurrence interval) is the period expressed in a number of years in which the annual observation is expected to return. It is the reciprocal value of the probability when expressed as a fraction: $T_{x}=1 / P_{x}$. The selection of the probability of exceedance $\left(\mathrm{P}_{\mathrm{x}}\right)$ or return period $\left(\mathrm{T}_{\mathrm{x}}\right)$ for design purposes is related to the damage the excess or the shortage of rainfall may cause, the risk one wants to accept and the lifetime of the project. Information on the rainfall depth that can be expected in a specific period under various weather conditions is required for management and planning purposes [4].

Iraq is sited between latitude $\left(29.00^{\circ}-37.22^{\circ} \mathrm{N}\right)$ and longitude $\left(38.45^{\circ}-48.30^{\circ} \mathrm{E}\right)$, figure (1). The climate of Iraq is generally as continental and subtropical semi-arid type whereas the mountainous regions are classified a Mediterranean climate. It is characterized by a very hot summer and a short cold winter and also by the breadth of the daily and annual temperature because of the lack of large water bodies that reduce the coldness of winter and summer heat [5].

The aim of this research is to study returns periods of rainfall in which contribute to the improvement of water management plans all over Iraq especially during dry seasons.

Journal of University of Babylon for Engineering Sciences by University of Babylon is licensed under a Creative Commons Attribution 4.0 International License. 
Earlier studies did not indicate using annual rainfall to study returns periods all over Iraq while one research has been found using this technique within the north of Iraq [6].

\section{Material:}

The materials used in this research were:

1- Annual and monthly rainfall records for (32) meteorological stations with their geographic coordinates from date of station operation to 2015 [7].

3- Rainfall returns periods method [8].

5- Excel, Grapher and Surfer programs demonstrating tables of results, contour maps and figures.

\section{Methodology:}

The annual rainfall data for (32) meteorological stations distributed in Iraq were obtained from date of stations operation to 2015. Rainfall returns periods method was used depending on to following formula [8]:

$$
\begin{gathered}
T x=\frac{1}{F} \\
F=\left(\frac{r}{n+1}\right) * 100
\end{gathered}
$$

Where Tx: returns periods in years, $F=$ Frequency of rainfall, $r=$ rank of each rainfall observations, $\mathrm{n}=$ number of rainfall observations.

The first step in the frequency analysis is the ranking of the rainfall data. After the rainfall data are ranked, a serial rank number (r) ranging from 1 to $n$ (number of observations) is assigned. Subsequently the probability have to be determined that should be assigned to each of the rainfall depths. If the data are ranked in descending order, the highest value first and the lowest value last, the probability is an estimate of the probability that the corresponding rainfall depth will be exceeded [4]. Finally Excel, Grapher and surfer programs used to present results and demonstrate contour map of rainfall in Iraq.

\section{Results and discussion:}

Table 1 and Fig. 1 show the geographical position of meteorological stations distributed in Iraq. Table 2 show the mean annual summation of rainfall obtained in (32) stations while Fig. 2 show the contour map of rainfall distribution all over Iraq.

\begin{tabular}{|c|c|c|c|c|c|c|c|}
\hline \multicolumn{2}{|c|}{ Location of stations } & \multirow{2}{*}{$\begin{array}{l}\text { Name of } \\
\text { Station }\end{array}$} & \multirow{2}{*}{$\begin{array}{c}\text { Station } \\
\text { No. }\end{array}$} & \multicolumn{2}{|c|}{ Location of stations } & \multirow{2}{*}{$\begin{array}{l}\text { Name of } \\
\text { Station }\end{array}$} & \multirow{2}{*}{$\begin{array}{c}\text { Station } \\
\text { No. }\end{array}$} \\
\hline Long. & Lat. & & & Long. & Lat. & & \\
\hline 444300 & 323300 & Ainaltamer & 1 & 433600 & 354500 & Makhmoor & 17 \\
\hline 471000 & 315100 & Amarah & 2 & 430900 & 361900 & Mosul & 18 \\
\hline 415700 & 342800 & Anah & 3 & 441900 & 315900 & Najaf & 19 \\
\hline 450400 & 325500 & Azizyah & 4 & 421500 & 320200 & Nukhaib & 20 \\
\hline 414400 & 360200 & Baaj & 5 & 461400 & 310500 & Nasiriyah & 21 \\
\hline 455700 & 330600 & Badra & 6 & 410100 & 342300 & Qaim & 22 \\
\hline 441400 & 331400 & Baghdad & 7 & 420600 & 364800 & Rabiah & 23 \\
\hline 432900 & 345600 & Baiji & 8 & 430900 & 332700 & Ramadi & 24 \\
\hline 474700 & 303400 & Basrah & 9 & 401700 & 330200 & Rutba & 25 \\
\hline
\end{tabular}

Table 1: Geographical position of meteorological stations in Iraq 
Journal of University of Babylon for Engineering Sciences, Vol. (27), No. (2): 2019.

\begin{tabular}{|l|c|c|c|c|c|c|c|}
\hline 445900 & 315900 & Diwaniyah & 10 & 435300 & 341100 & Samaraa & 26 \\
\hline 460300 & 321000 & Hai & 11 & 451600 & 311800 & Samawah & 27 \\
\hline 442700 & 322700 & Hilla & 12 & 415000 & 361900 & Sinjar & 28 \\
\hline 440100 & 323700 & Karbalaa & 13 & 422900 & 362200 & Tel-Afer & 29 \\
\hline 443200 & 335000 & Khalis & 14 & 434200 & 343400 & Tikrit & 30 \\
\hline 452600 & 341800 & Khanaqin & 15 & 443900 & 345300 & Tuz & 31 \\
\hline 442400 & 352800 & Kirkuk & 16 & 360900 & 440000 & Erbeel & 32 \\
\hline
\end{tabular}

Table 2: Mean annual rainfall $(\mathrm{mm})$ in meteorological station in Iraq

\begin{tabular}{|c|c|c|c|c|c|c|c|c||}
\hline $\begin{array}{c}\text { St. } \\
\text { No. }\end{array}$ & $\begin{array}{c}\text { Ave. Sum of } \\
\text { Rainfall } \\
(\mathbf{m m})\end{array}$ & $\begin{array}{c}\text { Duration } \\
\text { (years) }\end{array}$ & $\begin{array}{c}\text { St. } \\
\text { No. }\end{array}$ & $\begin{array}{c}\text { Ave. Sum } \\
\text { of } \\
\text { Rainfall } \\
(\mathbf{m m})\end{array}$ & $\begin{array}{c}\text { Duration } \\
\text { (years) }\end{array}$ & $\begin{array}{c}\text { St. } \\
\text { No. }\end{array}$ & $\begin{array}{c}\text { Ave. Sum of } \\
\text { Rainfall } \\
(\mathbf{m m})\end{array}$ & $\begin{array}{c}\text { Duration } \\
\text { (years) }\end{array}$ \\
\hline $\mathbf{1}$ & 92.469 & 20 & $\mathbf{1 2}$ & 108.981 & 40 & $\mathbf{2 3}$ & 367.12 & 38 \\
\hline $\mathbf{2}$ & 178.687 & 45 & $\mathbf{1 3}$ & 103.4592 & 65 & $\mathbf{2 4}$ & 110.512 & 40 \\
\hline $\mathbf{3}$ & 142.529 & 65 & $\mathbf{1 4}$ & 162.6836 & 30 & $\mathbf{2 5}$ & 116.65 & 78 \\
\hline $\mathbf{4}$ & 117.814 & 15 & $\mathbf{1 5}$ & 308.659 & 70 & $\mathbf{2 6}$ & 151.5433 & 50 \\
\hline $\mathbf{5}$ & 229.04 & 17 & $\mathbf{1 6}$ & 376 & 72 & $\mathbf{2 7}$ & 104.682 & 70 \\
\hline $\mathbf{6}$ & 204.843 & 15 & $\mathbf{1 7}$ & 306.914 & 25 & $\mathbf{2 8}$ & 389.308 & 63 \\
\hline $\mathbf{7}$ & 136.702 & 68 & $\mathbf{1 8}$ & 372.995 & 76 & $\mathbf{2 9}$ & 322.8445 & 64 \\
\hline $\mathbf{8}$ & 199.6981 & 65 & $\mathbf{1 9}$ & 94.05 & 55 & $\mathbf{3 0}$ & 181.878 & 25 \\
\hline $\mathbf{9}$ & 144.805 & 70 & $\mathbf{2 0}$ & 72.1554 & 45 & $\mathbf{3 1}$ & 254.026 & 45 \\
\hline $\mathbf{1 0}$ & 112.441 & 83 & $\mathbf{2 1}$ & 119.4807 & 74 & $\mathbf{3 2}$ & 449 & 40 \\
\hline $\mathbf{1 1}$ & 139.17 & 66 & $\mathbf{2 2}$ & 140.624 & 30 & & & \\
\hline
\end{tabular}

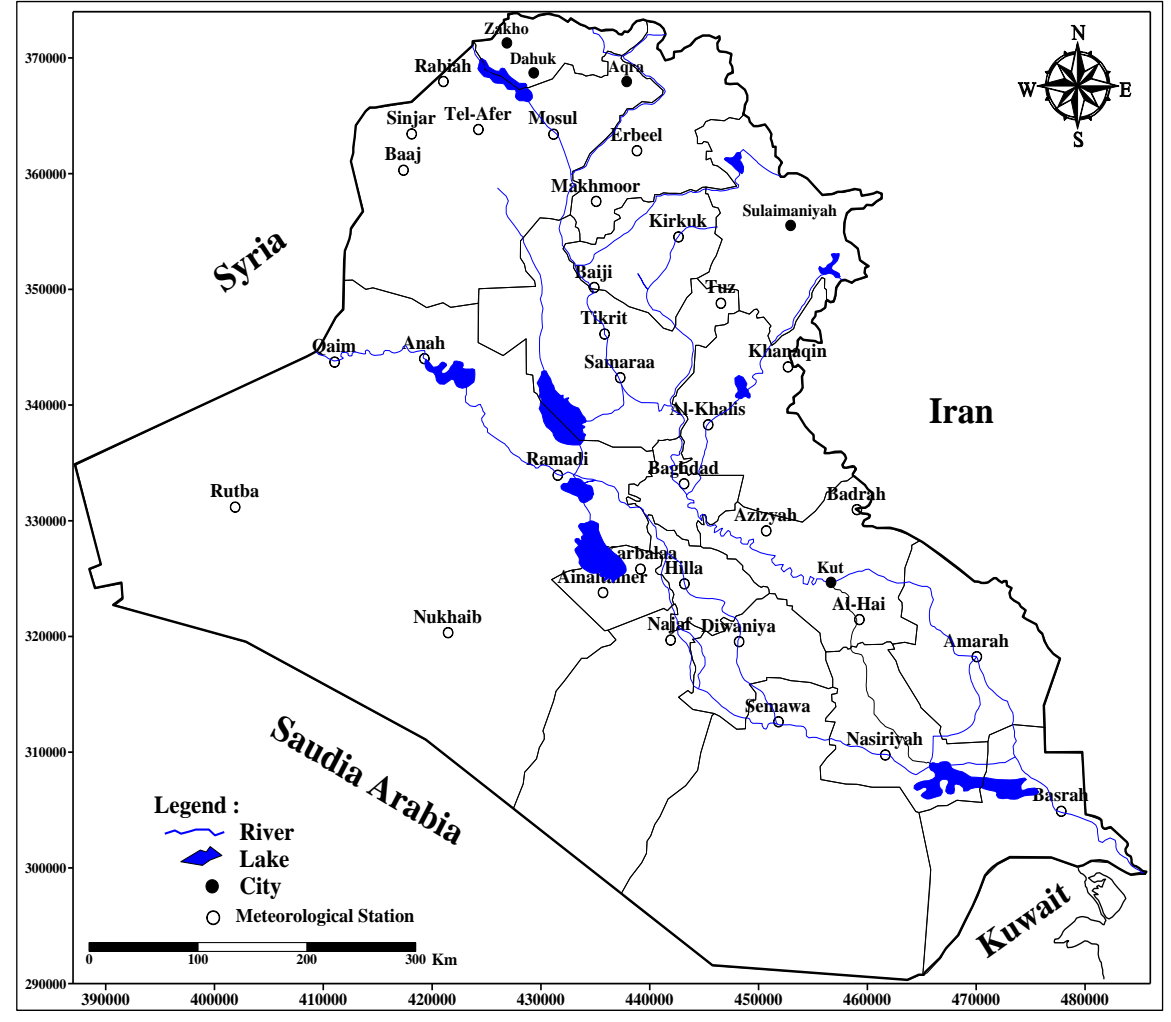

Fig. 1: Distribution map of Meteorological stations in Iraq. 


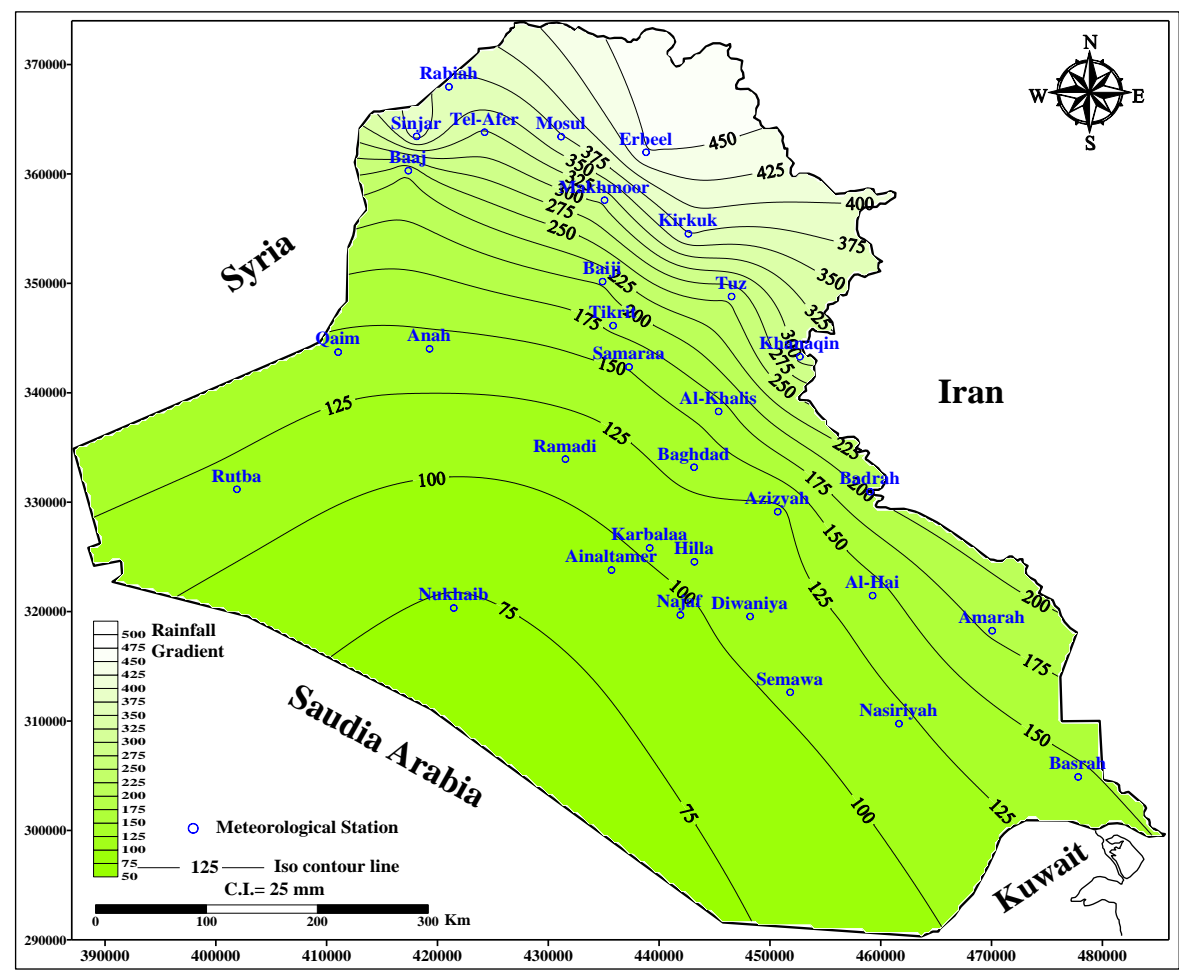

Fig. 2: Contour map of annual summation of Rainfall in Iraq.

It seems that mean annual summation of rainfall has a symmetrical increasing pattern from southwest towards north-east according to increasing ratio of rainfall in northern region of Iraq. The topography, atmospheric depression and the nature of air masses blowing from the surrounding areas play an important role in the variation of annual values of rainfall in these locations. As mentioned before the climate of Iraq is continental and subtropical semi-arid type whereas the mountainous regions in the north-eastern and north parts are classified a Mediterranean climate.

Using equations ( 1 and 2 ) mentioned above, the return periods of rainfall in (26) stations shown in Table 3 and Fig. 3. We used only stations that have at least thirty years observations in order to insure that return periods did not affected by low observations of rainfall. The estimated equation of returns periods versus mean annual rainfall was $(\mathrm{P}=130.595 * \log (\mathrm{T})+76.4755)$ with correlation of determination reached $(93.07 \%)$.

Depending on Table 4 which indicates the classification of meteorological events based on return periods, Table 5 show the normal distribution of rainfall all over Iraq according to the locations of meteorological stations.

Table 3: Returns periods obtained in (32) meteorological station in Iraq

\begin{tabular}{|c|c|c|c|c|c|}
\hline $\mathrm{r}$ & $\mathrm{F}$ & $\mathrm{T} \times($ Years $)$ & $\mathrm{P}$ (Rainfall mm) & Station no. & Duration \\
\hline \hline 1 & 0.037037 & 27 & 449 & 32 & 40 \\
\hline 2 & 0.074074 & 13.5 & 389.308 & 28 & 63 \\
\hline 3 & 0.111111 & 9 & 376 & 16 & 72 \\
\hline 4 & 0.148148 & 6.75 & 372.995 & 18 & 76 \\
\hline 5 & 0.185185 & 5.4 & 367.12 & 23 & 38 \\
\hline 6 & 0.222222 & 4.5 & 322.8445 & 29 & 64 \\
\hline 7 & 0.259259 & 3.857 & 308.659 & 15 & 70 \\
\hline 8 & 0.296296 & 3.375 & 254.026 & 31 & 45 \\
\hline
\end{tabular}


Journal of University of Babylon for Engineering Sciences, Vol. (27), No. (2): 2019.

\begin{tabular}{|c|c|c|c|c|c|}
\hline 9 & 0.333333 & 3 & 199.6981 & 8 & 65 \\
\hline 10 & 0.37037 & 2.7 & 178.687 & 2 & 45 \\
\hline 11 & 0.407407 & 2.454545 & 162.6836 & 14 & 30 \\
\hline 12 & 0.444444 & 2.25 & 151.5433 & 26 & 50 \\
\hline 13 & 0.481481 & 2.077 & 144.805 & 9 & 70 \\
\hline 14 & 0.518519 & 1.928 & 142.529 & 3 & 65 \\
\hline 15 & 0.555556 & 1.8 & 140.624 & 22 & 30 \\
\hline 16 & 0.592593 & 1.687 & 139.17 & 11 & 66 \\
\hline 17 & 0.62963 & 1.588 & 136.702 & 7 & 68 \\
\hline 18 & 0.666667 & 1.5 & 119.4807 & 21 & 74 \\
\hline 19 & 0.703704 & 1.421 & 116.65 & 25 & 78 \\
\hline 20 & 0.740741 & 1.35 & 112.441 & 10 & 83 \\
\hline 21 & 0.777778 & 1.286 & 110.512 & 24 & 40 \\
\hline 22 & 0.814815 & 1.227 & 108.981 & 12 & 40 \\
\hline 23 & 0.851852 & 1.174 & 104.682 & 27 & 65 \\
\hline 24 & 0.888889 & 1.125 & 103.4592 & 13 & 65 \\
\hline 25 & 0.925926 & 1.08 & 94.05 & 19 & 55 \\
\hline 26 & 0.962963 & 1.038 & 72.1554 & 20 & 45 \\
\hline \multicolumn{2}{|c|}{$\mathrm{N}+1=27$} & & & & \\
\hline
\end{tabular}

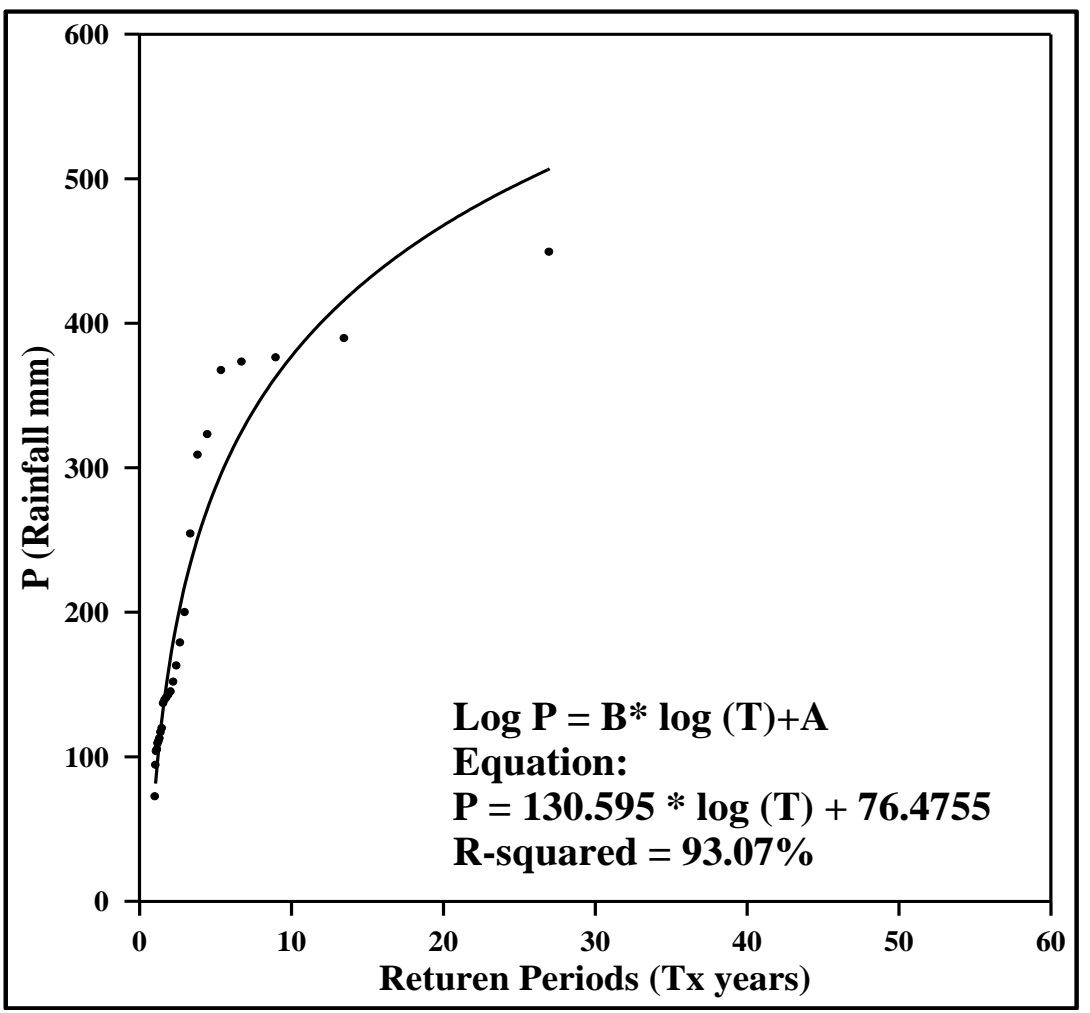

Fig. 3: the relationship of returns periods and rainfall in Iraq 
Table 4: Meteorological events classification based on rainfall returns periods [9].

\begin{tabular}{|c|c|}
\hline Classification & Returns periods (Years) \\
\hline Normal & $<6$ \\
\hline Abnormal & $6-10$ \\
\hline Very abnormal & $10-30$ \\
\hline Exceptional & $30-100$ \\
\hline Very exceptional & $>100$ \\
\hline
\end{tabular}

Table 5: Normality distribution of rainfall according to returns periods in Iraq.

\begin{tabular}{||c|c|c|c|c||}
\hline No. & $\begin{array}{c}\text { Classification of } \\
\text { meteorological events (P mm) }\end{array}$ & $\begin{array}{c}\text { rainfall returns } \\
\text { periods (years) }\end{array}$ & $\begin{array}{c}\text { Sum of } \\
\text { Stations }\end{array}$ & Area \\
\hline \hline 1 & Very abnormal & $13.5-27$ & 2 & Erbeel and Sinjar \\
\hline 2 & Abnormal & $6.75-9$ & 2 & Kirkuk and Mosul \\
\hline 3 & Normal & $1.038-5.4$ & 22 & All other stations \\
\hline
\end{tabular}

Fig. 4 show the distribution of rainfall returns periods in Iraq, where north-east region has characterized by very abnormal and abnormal events regarding rainfall $(\mathrm{P})$ in term of returns periods. The north-west, middle and southern regions of Iraq characterize by a normal distribution of rainfall. Food and Agriculture Organization (FAO) uses the following rules to determine dry, normal and humid weather conditions depending on returns periods:

- The weather condition in a period is called dry if the rainfall received during that period will be exceeded 4 out of 5 years, i.e. having returns periods of $80 \%$;

- The rainfall during a period is normal, if the rainfall received during that period will be exceeded in 1 out of 2 years. The returns period is equal to $50 \%$;

- The weather condition during a period is called humid if the rainfall received during that period has exceeded 1 out of 5 years, i.e. having returns periods of $20 \%$ [5].

Depending on this classification, Iraq has only two types of weather conditions, according to rainfall returns periods: the humid weather condition located in the northern east part and dry weather condition in the other parts of it. It seems that this classification is highly similar to the general classification of Iraqi climate as it is characterized by a very hot summer and a short cold winter of continental and subtropical semi-arid type. 


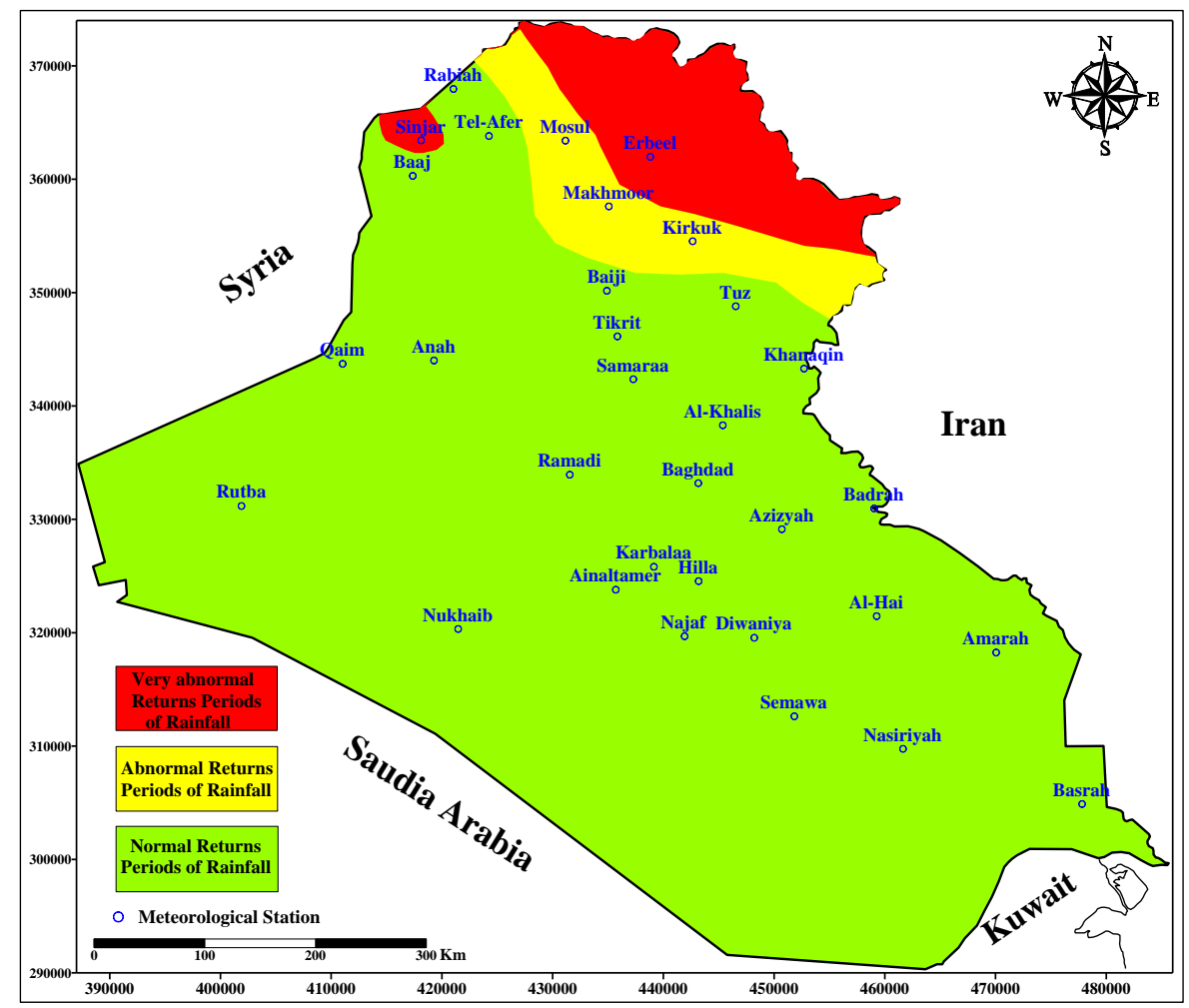

Fig. 4: Distribution of rainfall returns periods in Iraq

\section{Conclusion:}

1- Mean annual summation of rainfall has a symmetrical increasing pattern from southern west towards northern east, according to the increasing ratio of rainfall in northern region of Iraq.

2 - The estimated equation of return periods versus mean annual rainfall was $(\mathrm{P}=130.595 * \log (\mathrm{T})+$ 76.4755).

3- The northern east region of Iraq has characterized by very abnormal and abnormal events regarding rainfall $(\mathrm{P})$ in term of returns periods, while the northern west, middle and south regions characterize by normal distribution of rainfall.

4- Depending on (FAO) classification, Iraq has only two types of weather conditions according to rainfall returns periods: the humid weather condition located in the northern east part and dry weather condition in the other parts of it.

\section{Recommendations:}

Water harvesting and dam constructions are highly recommended in north and northern east of Iraq due to highly mean annual rainfall as well as the very abnormal and abnormal meteorological events obtained by returns periods calculation related to rainfall observations. These two regions contribute in highly water surplus which increase surface water storage in dams and lakes as well as groundwater natural recharge.

\section{Conflicts of Interest}

The author declares that they have no conflicts of interest. 


\section{References:}

[1] R. Kumar and A. Bhardwaj, "Probability analysis of return period of daily maximum rainfall in annual data set of Ludhiana, Punjab", Indian Journal of Agriculture Resource. Vol. 49, No.2, pp. 160-164. 2015.

[2] D. Small, S. Islam and R. M. Vogel, Trends in precipitation and stream flow in the eastern US: Paradox or perception? Geophysical Research Letters. Vol. 33, No. 3, 2006.

[3] H.S. Juny, H.L. Gyu, and H.O. Jai, Interpretation of the transient variation of precipitation amount in Seoul. American Meteorological Society. Vol. 14, No. 13, 2001.

[4] D. RAES and K.U. Leuven, Frequency analysis of rainfall data. Inter-University Programme in Water Resources Engineering. (IUPWARE) Leuven, Belgium, 2004.

[5] FAO. Towards sustainable agricultural development in Iraq: the Transition from Relief, Rehabilitation and Reconstruction to Development, Rome, 2003.

[6] H.I. Al-Sudani, "Hyrogeological System of Debagah Basin In North of Iraq", Ph.D. Thesis , Uni. of Baghdad, Baghdad, Iraq, 2003.

[7] Iraqi meteorological Organization and Seismology. Meteorological data of (32) meteorological station for different periods, Ministry of Transportation. Baghdad. Iraq. 2015.

[8] C.T. Haan, Statistical methods in Hydrology. Ames, Iowa, USA, 1986.

[9] WMO. On the statistical analysis of series of observations. World Meteorological Organization, WMO $-\mathrm{N}^{\circ}$ 415. Geneva, Switzerland.1990. 
Journal of University of Babylon for Engineering Sciences, Vol. (27), No. (2): 2019.

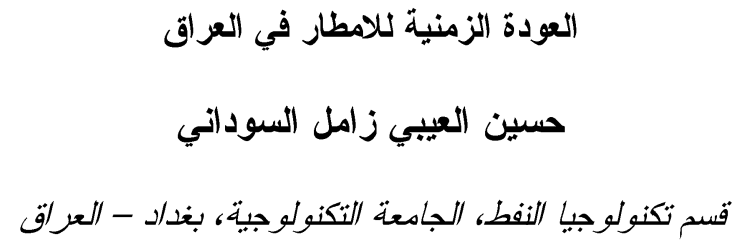

dr.hussein_alsudani@yahoo.com, 150098@uotechnology.edu.iq

\section{خلاصة}

بيانات الساقط المطري في اثثين وثلاثين محطة مناخية موزعة غلى العراق نم الاستعانة بها لايجاد العودة الزمنية للامطار

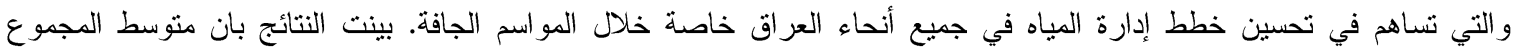

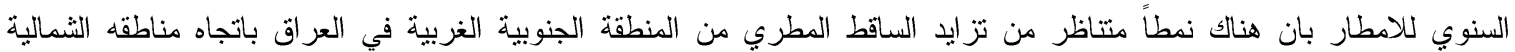

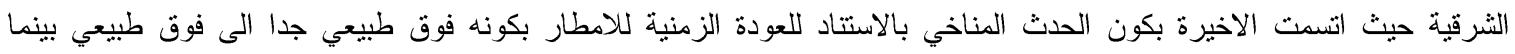
امتازت باقي مناطق العر اق بحدث مناخي متمثل بتوزيع طييعي للامطار بدلالة العودة الزمنية لها. اوضحت النتائج بان العراق بتنميز بنوعين فقط من الظروف الجوية حسب فتزات سقوط الأمطار منتظة بحالة الطقس الرطب الموجودة في الجزء الثمالي الثرقي والظروف الجوية الجافة في الأجزاء الأخرى منه. الكلمات الداله: العودة الزمنية للامطار، العراق. 